\title{
Transactivation via the human glucocorticoid and mineralocorticoid receptor by therapeutically used steroids in CV-1 cells: a comparison of their glucocorticoid and mineralocorticoid properties
}

\author{
Claudia Grossmann ${ }^{1}$, Tim Scholz ${ }^{1}$, Marina Rochel ${ }^{1}$, Christiane Bumke-Vogt $^{1}$, Wolfgang Oelkers ${ }^{1}$, \\ Andreas F H Pfeiffer ${ }^{1,2}$, Sven Diederich ${ }^{1,2}$ and Volker Bähr ${ }^{1,2}$ \\ ${ }^{1}$ Department of Endocrinology, Diabetes and Nutrition, Charité-Universitätsmedizin Berlin, Campus Benjamin Franklin, Hindenburgdamm 30 , \\ 12200 Berlin, Germany and ${ }^{2}$ Department of Clinical Nutrition, German Institute of Human Nutrition Potsdam, Bergholz-Rehbrücke, Germany \\ (Correspondence should be addressed to Volker Bähr, Department of Endocrinology, Diabetes and Nutrition, Charité-Universitätsmedizin Berlin, \\ Campus Benjamin Franklin, Hindenburgdamm 30, 12200 Berlin, Germany; Email: baehr@ukbf.fu-berlin.de)
}

\begin{abstract}
Background: Glucocorticoids (GCs) are commonly used for long-term medication in immunosuppressive and anti-inflammatory therapy. However, the data describing gluco- and mineralo-corticoid (MC) properties of widely applied synthetic GCs are often based on diverse clinical observations and on a variety of in vitro tests under various conditions, which makes a quantitative comparison questionable. Method: We compared MC and GC properties of different steroids, often used in clinical practice, in the same in vitro test system (luciferase transactivation assay in CV-1 cells transfected with either hMR or $\mathrm{hGR} \alpha$ expression vectors) complemented by a system to test the steroid binding affinities at the hMR (protein expression in T7-coupled rabbit reticulocyte lysate).

Results and Conclusions: While the potency of a GC is increased by an 11-hydroxy group, both its potency and its selectivity are increased by the $\Delta 1$-dehydro-configuration and a hydrophobic residue in position 16 (16-methylene, 16 $\alpha$-methyl or 16ß-methyl group). Almost ideal GCs in terms of missing MC effects, as defined by our in vitro assay, are therefore prednylidene, budesonide, beclomethasone and betamethasone.

The MC potency of a steroid is increased by a $9 \alpha$ - or a $6 \alpha$-fluoro substituent. A hydrophilic substituent in position 16 (like 16-hydroxylation in triamcinolone) decreases both $\mathrm{MC}$ and GC properties. As no substituent that leads to an isolated reduction of GC activity could be characterized in our experiments, $9 \alpha$-fluorocortisol, the most frequently used steroid for MC substitution, seems to be the best choice of available steroids for this purpose.
\end{abstract}

European Journal of Endocrinology 151 397-406

\section{Introduction}

Glucocorticoids (GCs) are potent suppressors of the immune response, which makes them frequently used agents in long-term anti-inflammatory therapy (1-3). Besides their GC properties, all of these steroids possess mineralocorticoid (MC) properties causing unwanted side effects such as fluid-electrolyte imbalance and hypertension (4). This is most likely due to the close structural relationship of the glucocorticoid receptor (GR) and the mineralocorticoid receptor (MR) (5) and their overlapping signalling pathways. Both receptors belong to the steroid receptor superfamily, a subgroup of the nuclear receptors. The first one also includes the androgen, progesterone and estrogen receptor, the latter the receptors for thyroid hormone, vitamin D and retinoic acids, and a large group of orphan receptors $(5-7)$. The physiological human ligands of the MR and the GR are aldosterone and cortisol respectively. In the absence of ligands, the MR and the GR are associated with a heteromeric complex containing hsp70, hsp90 and other chaperone molecules (8-10). After ligand binding, a conformational change and partial dissociation of the complex occur, followed by nuclear translocation $(11,12)$. Within the nucleus, the ligand-activated receptors regulate transcription via three major pathways. The one described best, transactivation, requires receptor dimerization and binding to cis-activating palindromic glucocorticoid response elements (GREs) located in the promoter region of target genes $(13,14)$. So far no response elements specific for the mineralocorticoid receptor have been described. Another way of gene regulation is the binding to negative glucocorticoid response elements (nGREs), 
leading to transrepression (15). The third one is transrepression by inactivation of transcription factors such as AP-1, NF-кB and NF-AT, which seems to be the main mechanism in the anti-inflammatory action of natural and synthetic glucocorticoids $(1,16,17)$. Additional extragenomic effects have been described both for mineralo- and gluco-corticoids (18-20).

The scientific origin of many data describing the agonistic properties of widespread synthetic GCs is elusive. As they are based on several in vivo and in vitro tests under varying conditions and with different parameters measured $(4,21-28)$, it is almost impossible to compare them in a reliable way. Our aim was to evaluate the glucocorticoid potencies of different therapeutically used steroids systematically by employing a human GR (hGR)-dependent transactivation assay in CV-1 cells. In a second step, we intended to compare their mineralocorticoid potencies in an equivalent assay differing from the first one merely by the presence of the human MR (hMR) instead of the hGR. To complement the latter transactivation data, we investigated their prerequisite, the steroid binding to the hMR. The intention of this approach was to facilitate the optimizing of long-term steroid therapies and the prediction of $\mathrm{GC}$ and $\mathrm{MC}$ properties of future synthetic steroids.

\section{Materials and methods}

\section{Steroids}

The steroids were puchased from Bristol Myers Squibb GmbH (Regensburg, Germany), Glaxo Research and Development (Stevenage, UK), Merck, MMDRI-Lepetit Research Center (Gerenzano, Italy), Paesel and Lorei (Hannover, Germany), Schering (Berlin, Germany),
Sigma Chemical (St Louis, MO, USA) (Table 1). For a better understanding of the formulas, see Fig. 1.

\section{Plasmids}

pRShMR and pRShGR were gifts from Prof. R Evans (The Salk Institute, La Jolla, CA, USA). The plasmids contain the coding sequence for the hMR and the hGR $\alpha$ respectively, under the control of the Rous sarcoma virus long terminal repeat and the SV40 origin of replication. The structure of the pRShGR is identical to that of the pRShMR with the exception of the part containing the hMR coding nucleotides which has been replaced by the coding sequence of the $\operatorname{hGR} \alpha(5,29)$.

pMMTV-Luc was kindly provided by Dr B Gellersen (Hamburg, Germany). It contains the cDNA for firefly luciferase, which catalyses a light emitting reaction on addition of the proper substrate. Transcription is controlled by glucocorticoid responsive elements present in the mouse mammary tumor virus long terminal repeat (MMTV-LTR) (30) immediately upstream from the luciferase sequence (31).

The pRL-SV40 vector (Promega, Madison, WI, USA) causes constitutive expression of Renilla luciferase and does not require post-translational modification for activity (32). It served as an internal standard to normalize firefly luciferase light emission measurements with regard to transfection efficiency and the number of cells in each well.

\section{Cell culture, transfection and transactivation assay}

The transfections and transactivation assays were carried out in CV-1 cells (african green monkey kidney

Table 1 Steroids.

\begin{tabular}{|c|c|c|}
\hline Substance & Formula & Source \\
\hline Dehydroepiandrosterone & 5-androstene-3 $\beta$-ol-17-one & Sigma \\
\hline Progesterone & 4-pregnene-3,20-dione & Sigma \\
\hline Aldosterone & 4-pregnene-18-al-11 $\beta, 21$-diol-3,20-dione & Sigma \\
\hline Cortisone & 4-pregnene-17ß,21-diol-3,11,20-trione & Sigma \\
\hline Cortisol & 4-pregnene-11 $\beta, 17 \alpha, 21$-triol-3,20-dione & Sigma \\
\hline $6 \alpha$-fluorocortisol & 4-pregnene- $6 \alpha$-fluoro-11 $\beta, 17 \alpha, 21$-triol-3,20-dione & Schering \\
\hline $9 \alpha$-fluorocortisol & 4-pregnene-9 $\alpha$-fluoro-11 $\beta, 17 \alpha, 21$-triol-3,20-dione & Merck \\
\hline Prednisone & 1,4-pregnadiene-17 $\alpha, 21$-diol-3,11,20-trione & Sigma \\
\hline Prednisolone & 1,4-pregnadiene-11 $\beta, 17 \alpha, 21$-triol-3,20-dione & Sigma \\
\hline $6 \alpha$-methylprednisolone & 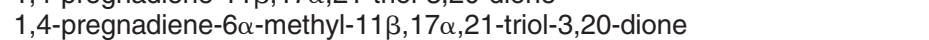 & Schering \\
\hline Prednylidene & 1,4-pregnadiene-16-methylen-11 $\beta, 17,21$-triol-3,20-dione & Merck \\
\hline Budesonide & 1,4-pregnadiene-16,17-butylidenbis(oxy)-11 $\beta, 21$-diol-3,20-dione & Sigma \\
\hline Deacetyldeflacacort & 1,4-pregnadiene-16,17-methyloxazoline-11 $\beta, 21$-diol-3,20-dione & MMDRI \\
\hline Deflazacort & 1,4-pregnadiene-16,17-methyloxazoline- $11 \beta, 21$-diol-3,20-dione 21 -acetate & MMDRI \\
\hline Isoflupredone & 1,4-pregnadiene-9 $\alpha$-fluoro- $11 \beta, 17 \alpha, 21$-triol-3,20-dione & Paesel \\
\hline Dexamethasone & 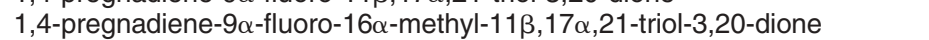 & Sigma \\
\hline Betamethasone & 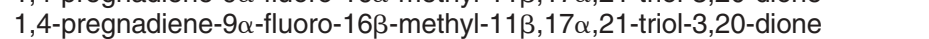 & Glaxo \\
\hline Triamcinolone & 1,4-pregnadiene-9 $\alpha$-fluoro- $11 \beta, 16 \alpha, 17 \alpha, 21$-tetrahydroxy-3,20-dione & Squibb \\
\hline Beclomethasone & 1,4-pregnadiene-9 $\alpha$-chloro-16 $\beta$-methyl- $11 \beta, 17 \alpha, 21$-triol-3,20-dione & Sigma \\
\hline Flumethasone & 1,4-pregnadiene- $6 \alpha, 9 \alpha$-difluoro-16 $\alpha$-methyl- $11 \beta, 17 \alpha, 21$-triol-3,20-dione & Sigma \\
\hline
\end{tabular}




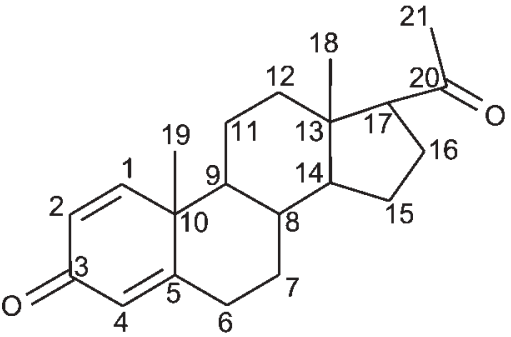

1,4-pregnadiene-3,20-dione<smiles>CC12CCC(=O)C=C1CCC1C2[C@@H](O)CC2(C)C1CC[C@]2(O)C(=O)CO</smiles>

cortisol<smiles>CC12C=CC(=O)C=C1CCC1C2[C@@H](O)CC2(C)C1CC[C@@]2(O)C(=O)CO</smiles>

prednisolone<smiles>C[C@H]1CC2C3CCC4=CC(=O)C=CC4(C)[C@@]3(F)[C@H](O)CC2(C)[C@]1(O)C(=O)CO</smiles>

dexamethasone

Figure 1 Structural formulas for 1,4-pregnadiene-3,20-dione, cortisol (4-pregnene-11 $\beta, 17 \alpha, 21$-triol-3,20-dione), prednisolone (1,4-pregnadiene-11 $\beta, 17 \alpha, 21$-triol-3,20-dione) and dexamethasone (1,4-pregnadiene-9 $\alpha$-fluoro-16 $\alpha$-methyl-11 $\beta, 17 \alpha, 21$-triol-3,20-dione).

cells; American Type Culture Collection) in 24-well plates as described previously (33). The 80-90\% confluent cells (approximately 50000 per well) were transiently transfected with a cationic lipid reagent (Lipofectamine Plus Method, Life Technologies, Karlsruhe, Germany). In each well, $0.02 \mu \mathrm{g}$ of pRL-SV40 and $0.15 \mu \mathrm{g}$ of pMMTV-Luc were co-transfected together with either $0.3 \mu \mathrm{g}$ of pRShMR or pRShGR. After $24 \mathrm{~h}$ of incubation, different steroids were added in charcoal stripped fetal calf serum in concentrations ranging from $10^{-10}$ to $10^{-5} \mathrm{M}$ for the GR and from $10^{-11}$ to $10^{-6} \mathrm{M}$ for the MR. The CV-1 cells were lysed $24 \mathrm{~h}$ later in passive lysis buffer from the DualLuciferase Reporter Assay System (Promega, Madison, WI, USA). The activity of constitutively expressed Renilla luciferase and hormone-dependently expressed firefly luciferase were measured in a Berthold LB 9501 luminometer (Berthold Technologies, Bad Wildbad, Germany). The transactivational response was determined as the ratio of firefly to Renilla luciferase activity normalized to the maximum activity of reference substances: dexamethasone for GR- and aldosterone for MR-mediated transactivation. The resulting graphs start at a baseline effect and asymptotically approach individual maximal effects (Fig. 2). To characterize these curves, we calculated the concentration $\left(\mathrm{EC}_{50}\right)$ at which $50 \%$ of the asymptotical maximum effect $\left(E_{\max }\right)$ was achieved by iterative nonlinear regression using the Prism software (Version 3.02) from GraphPad (San Diego, CA, USA). Differences in $\mathrm{EC}_{50}$ values were tested for significance with the same software by means of a modified two-tailed $t$-test.

\section{Coupled cell-free transcription and translation of $h M R$}

Expression of hMR from the plasmid pchMR (kindly provided by Prof. M Rafestin-Oblin, Institut National de la Sante et de la Recherche Medicale, Paris, France) containing the hMR cDNA (34) was performed in a coupled rabbit reticulocyte lysate system for transcription and translation $\left(\mathrm{TNT}^{\mathrm{R}}\right.$ from Promega, Madison, WI, USA). T7 RNA polymerase was used for synthesis of hMR mRNA which was translated to hMR during incubation of $90 \mathrm{~min}$ at $30{ }^{\circ} \mathrm{C}$ according to the manufacturer's instruction.

\section{Steroid-binding competition at the hMR}

$\mathrm{H}$-aldosterone ( $5 \mathrm{nM}$ ) was incubated in the absence or presence of unlabelled aldosterone $(5 \mu \mathrm{M})$ for determination of specific and nonspecific ligand binding. Different unlabelled steroids were tested for competition at the hMR in increasing concentrations $\left(10^{-11}\right.$ to $\left.10^{-6} \mathrm{M}\right)$ as duplicates. The incubation volume was $25 \mu \mathrm{l}$, and steroids were dissolved in $12.5 \mu \mathrm{l}$ of TEGDW buffer (20 mM Tris-HCl pH 7.4, 1 mM EDTA, $1 \mathrm{mM}$ dithiothreitol, $20 \mathrm{mM}$ sodium tungstate and $10 \%$ glycerol) mixed with $0.2 \%$ ethanol. $12.5 \mu \mathrm{l}$ aliquots of reticulocyte lysate containing synthesized hMR were added to 

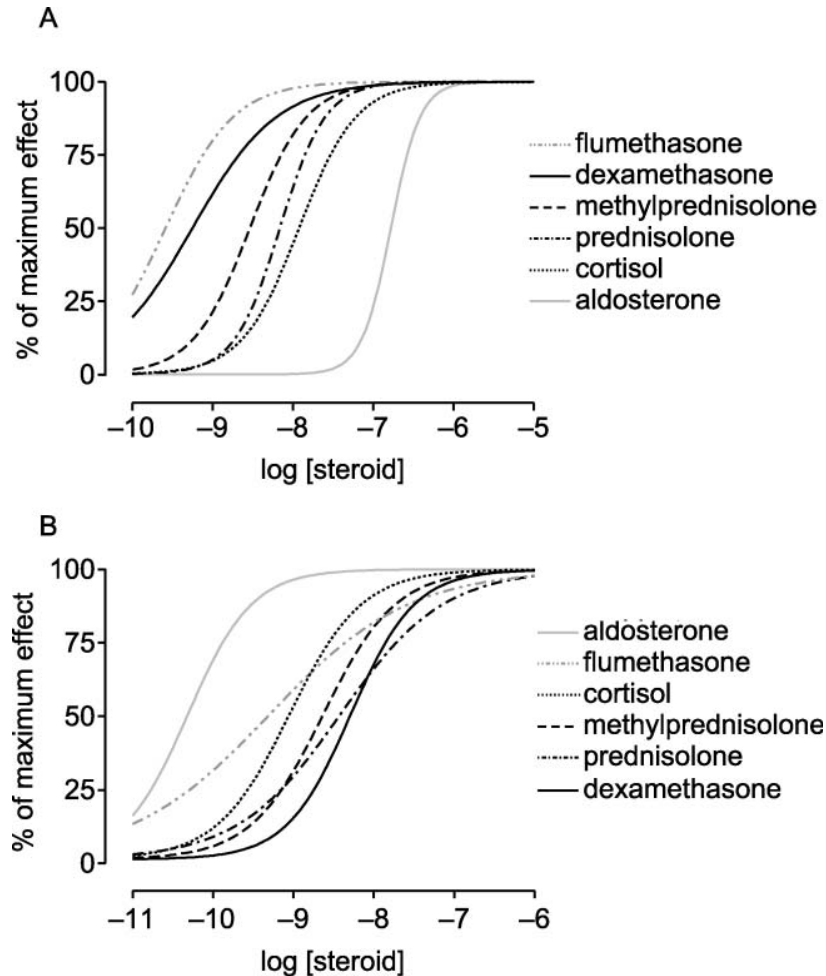

Figure 2 Nonlinear regression curves for the concentrationresponse-relationship of transactivation by six representative steroids in CV-1 cells. To facilitate the comparison of $\mathrm{EC}_{50}$ values, the response is shown as percentage of the maximum effect which differs for each steroid-receptor combination and is given in Tables 2 and 3. (A) Transactivation via hGR $\alpha$ at steroid concentrations from $10^{-10}$ to $10^{-5} \mathrm{M}$. (B) Transactivation via hMR at steroid concentrations from $10^{-11}$ to $10^{-6} \mathrm{M}$.

ice-cold steroid solution in TEGDW and incubated for $4 \mathrm{~h}$ at $4{ }^{\circ} \mathrm{C}$ for steroid binding. Unbound steroids were separated using dextrane-coated charcoal (DCC): $1 \mathrm{ml}$ of $0.5 \%$ DCC in TEGDW was added to each $25 \mu$ l binding assay mixture, shaken for $7 \mathrm{~min}$ on ice and centrifuged at $14000 \mathrm{~g}$ for $10 \mathrm{~min}$ at $4{ }^{\circ} \mathrm{C}$. Aliquots of $780 \mu \mathrm{l}$ from the supernatant were added to $10 \mathrm{ml}$ of Ultima Gold solution (Packard Bioscience, Groningen, Netherlands) and analyzed in a $\beta$-counter (Winspectral, 1414 PerkinElmer, Turku, Finland). D.p.m. values were calculated online using an external standard. The affinities of the steroids to the hMR were calculated as $\mathrm{IC}_{50}$ values by nonlinear regression with Prism (see above) assuming one site competition.

\section{Results}

To ensure that our $\mathrm{CV}-1$ cell system does not contain relevant amounts of endogenous GR or MR, the transactivation activities of the two reference substances, dexamethasone and aldosterone, were measured in CV-1-cells that had not been transfected with steroid receptor expression vectors. Likewise, the system was tested for endogenous steroids by measuring the transactivation activity without prior addition of steroids but after transfection with hMR or hGR expression vectors. Neither approach led to relevant transactivation. In assays with receptor transfection, aldosterone induced half-maximal transactivation via the MR at concentrations about one order of magnitude below the $\mathrm{EC}_{50}$ observed with dexamethasone and the GR (Fig. 2).

All GC potencies calculated by our in vitro transactivation assay are listed in Table 2. Based on these results, the main structural features determining GC potency are the size and the polarity of the substituent in position 6 or 16 (Table 4). A hydrophobic residue increases GC activity of a steroid (statistically significant enhancement with $6 \alpha$-methyl and 16-methylene substitution, tendency not reaching significance with $16 \alpha$ - and 16 $\beta$-methyl and 16,17-methyloxazoline groups). The more polar 16-hydroxy substitution decreases GC potency.

The other important position for GC activity is the 11-hydroxy group, present in the glucocorticoids tested but not in aldosterone (hemiacetal form), which consequently possesses a low GC potency. The $6 \alpha$ - and $9 \alpha$-fluorination leads to increased GC transactivation, which also applies to the $\Delta 1$-dehydro-configuration (in prednisolone).

$6 \alpha$ - or $9 \alpha$ - fluorination and the keto configuration of the 11-hydroxy group affect the MC potencies (Table 3) qualitatively in the same way as the GC potencies (Table 4). However, opposite to the effect observed with the GR, the $\Delta 1$-dehydro-configuration and the 16-methylene, 16 $\alpha$-methyl and 16 $\beta$-methyl groups attenuate $\mathrm{MC}$ potency.

In binding competition experiments with the hMR (Fig. 3), we found displacement of the ligand 3H-aldosterone decreasing in strength from $9 \alpha$-fluorocortisol, $6 \alpha$-fluorocortisol and cortisol to aldosterone, $6 \alpha$ methylprednisolone and prednisolone (nearly the same displacement by the last three steroids), followed by dexamethasone, prednylidene, oxo-dexamethasone and cortisone. Thus, the MR affinity parallels the strength of MC agonism in our transactivation assay, with the exception of a discrepancy between the relatively weak binding of aldosterone (e.g. compared with cortisol) and its high transactivational potency.

\section{Discussion}

The traditional ways to measure GC and MC potencies of steroids refer to anti-inflammatory (rat ear edema test, McKenzie vasoconstriction test) or metabolic (liver glycogen assay) effects and sodium retention. Depending on the testing conditions, absolute potency values vary considerably. It is therefore extremely difficult, if not impossible, to arrange the individual results from different research groups to compile a comprehensive list $(4,21-28)$. Considering these very complex 
Table 2 Transactivation via the human glucocorticoid receptor (hGR). $\mathrm{EC}_{50}$ values and $\mathrm{E}_{\max }$ of steroids tested in $\mathrm{CV}$-1 cells cotransfected with pRShGR, pMMTV-Luc and pRL-SV40. The substances are arranged from top to bottom from highest to lowest glucocorticoid (GC) potency. The $\mathrm{EC}_{50}$ values of cortisone, dehydroepiandrosterone, prednisone and progesterone could not be calculated because no effect saturation was reached under the given experimental conditions (n.c. $=$ not calculable). For the relative GC potencies, cortisol was chosen as the standard substance. GC potencies in literature are taken from references (4, 21-28) n.d.: no data found.

\begin{tabular}{|c|c|c|c|c|}
\hline Steroid & $\mathrm{E}_{\max } \pm \mathrm{SE}$ & $\mathrm{EC}_{50}[\mathrm{M}]$ & GC potency & GC potency in literature \\
\hline Budesonide & $0.95 \pm 0.03$ & $4.57 \times 10^{-11}$ & 263 & 250 \\
\hline Prednylidene & $1.37 \pm 0.03$ & $6.61 \times 10^{-11}$ & 182 & 4 \\
\hline Beclomethasone & $0.98 \pm 0.04$ & $1.91 \times 10^{-10}$ & 63 & 20 \\
\hline Flumethasone & $1.57 \pm 0.07$ & $2.60 \times 10^{-10}$ & 46 & n.d. \\
\hline Betamethasone & $0.95 \pm 0.02$ & $2.64 \times 10^{-10}$ & 45 & 25 \\
\hline Dexamethasone & $1.00 \pm 0.02$ & $5.61 \times 10^{-10}$ & 21 & 25 \\
\hline Isoflupredone & $1.24 \pm 0.03$ & $8.77 \times 10^{-10}$ & 14 & 20 \\
\hline $9 \alpha$-fluorocortisol & $0.90 \pm 0.02$ & $1.90 \times 10^{-9}$ & 6.3 & 10 \\
\hline $6 \alpha$-fluorocortisol & $0.90 \pm 0.02$ & $2.63 \times 10^{-9}$ & 4.6 & n.d. \\
\hline $6 \alpha$-methylprednisolone & $1.13 \pm 0.03$ & $2.92 \times 10^{-9}$ & 4.1 & 5 \\
\hline Desacetyldeflazacort & $1.28 \pm 0.03$ & $4.37 \times 10^{-9}$ & 2.7 & 4 \\
\hline Prednisolone & $0.78 \pm 0.02$ & $6.90 \times 10^{-9}$ & 1.7 & 4 \\
\hline Cortisol & $1.13 \pm 0.03$ & $1.20 \times 10^{-8}$ & 1 & 1 \\
\hline Deflazacort & $1.02 \pm 0.04$ & $1.25 \times 10^{-8}$ & 0.96 & 4 \\
\hline Triamcinolone & $0.78 \pm 0.02$ & $3.42 \times 10^{-8}$ & 0.35 & 4 \\
\hline Aldosterone & $1.11 \pm 0.03$ & $1.66 \times 10^{-7}$ & 0.07 & $0-0.1$ \\
\hline Cortisone & n.c. & n.c. & n.c. & 0.8 \\
\hline Dehydroepiandrosterone & n.c. & n.c. & n.c. & 0 \\
\hline Prednisone & n.c. & n.c. & n.c. & 4 \\
\hline Progesterone & n.c. & n.c. & n.c. & $0-0.3$ \\
\hline
\end{tabular}

in vivo actions, we tried to focus on a level that allows the comparison of several steroids in vitro. However, even though the results from our transactivation assays with the GR and MR were surprisingly congruent with GC and MC potency lists contained in most standard textbooks of medicine and pharmacology (see Tables 2 and 3 for comparison of relative GC and MC potencies), it is obvious that conclusions with respect to the use of GCs in humans must be drawn with caution.

Table 3 Transactivation via the human mineralocorticoid receptor (hMR). $\mathrm{EC}_{50}$ values and $\mathrm{E}_{\max }$ of steroids tested in $\mathrm{CV}-1$ cells cotransfected with pRShMR, pMMTV-Luc and pRL-SV40. The substances are arranged from top to bottom from highest to lowest mineralocorticoid (MC) potency. The $\mathrm{EC}_{50}$ values of prednisone, cortisone, deflazacort and dehydroepiandrosteorne could not be calculated because no effect saturation was reached under the given experimental conditions (n.c. = not calculable). For the relative MC potencies, aldosterone was chosen as the standard substance. MC potencies in literature are taken from references (4, 21-28) (n.d.: no data found).

\begin{tabular}{|c|c|c|c|c|}
\hline Steroid & $E_{\max } \pm S E$ & $\mathrm{EC}_{50}[\mathrm{M}]$ & MC potency & MC potency in literature \\
\hline $9 \alpha$-fluorocortisol & $1.814 \pm 0.22$ & $4.78 \times 10^{-12}$ & 10 & 1 \\
\hline Isoflupredone & $1.513 \pm 0.47$ & $7.00 \times 10^{-12}$ & 7 & n.d. \\
\hline $6 \alpha$-fluorocortisol & $1.794 \pm 0.12$ & $4.14 \times 10^{-11}$ & 1.2 & n.d. \\
\hline Aldosterone & $1.00 \pm 0.02$ & $4.80 \times 10^{-11}$ & 1.0 & 1 \\
\hline Flumethasone & $1.669 \pm 0.07$ & $4.94 \times 10^{-10}$ & 0.097 & n.d. \\
\hline Cortisol & $1.020 \pm 0.04$ & $8.95 \times 10^{-10}$ & 0.054 & 0.0025 \\
\hline $6 \alpha$-methylprednisolone & $1.845 \pm 0.05$ & $2.31 \times 10^{-9}$ & 0.021 & 0.0013 \\
\hline Prednisolone & $1.456 \pm 0.05$ & $3.78 \times 10^{-9}$ & 0.013 & 0.002 \\
\hline Dexamethasone & $1.502 \pm 0.06$ & $5.09 \times 10^{-9}$ & 0.0094 & 0 \\
\hline Budesonide & $0.822 \pm 0.04$ & $7.62 \times 10^{-9}$ & 0.0063 & n.d. \\
\hline Progesterone & $0.239 \pm 0.01$ & $9.02 \times 10^{-9}$ & 0.0053 & 0 \\
\hline Desacetyldeflazacort & $0.497 \pm 0.02$ & $1.02 \times 10^{-8}$ & 0.0047 & n.d. \\
\hline Betamethasone & $0.902 \pm 0.02$ & $1.26 \times 10^{-8}$ & 0.0038 & 0 \\
\hline Beclomethasone & $0.520 \pm 0.02$ & $4.11 \times 10^{-8}$ & 0.0012 & n.d. \\
\hline Prednylidene & $0.772 \pm 0.02$ & $4.27 \times 10^{-8}$ & 0.0011 & 0 \\
\hline Triamcinolone & $0.458 \pm 0.05$ & $2.91 \times 10^{-7}$ & 0.0002 & 0 \\
\hline Cortisone & n.c. & n.c. & n.c. & 0.002 \\
\hline Deflazacort & n.c. & n.c. & n.c. & n.d. \\
\hline Dehydroepiandrosterone & n.c. & n.c. & n.c. & n.d. \\
\hline Prednisone & n.c. & n.c. & n.c. & 0.002 \\
\hline
\end{tabular}


Table 4 Different functional groups and their effects on the glucocorticoid (GC) and mineralocorticoid (MC) activity of a steroid $\uparrow$ Enhancement or $\downarrow$ attenuation of the glucocorticoid (upper part) or mineralocorticoid activity by functional groups (left column). Compared are compounds without the corresponding group (column second from the right) with those with the group (right column). Differences are significant $(p<0.05)$, except for $(\uparrow)$ or $(\downarrow)$ which show trends $(p>0.05)$.

\begin{tabular}{|c|c|c|c|c|c|c|c|}
\hline \multicolumn{4}{|c|}{ GC activity } & \multicolumn{4}{|c|}{ MC activity } \\
\hline $\begin{array}{l}\text { Functional } \\
\text { group }\end{array}$ & Effect & Examples & & $\begin{array}{l}\text { Functional } \\
\text { group }\end{array}$ & Effect & Examples & \\
\hline 11-keto & $\downarrow$ & $\begin{array}{l}\text { Cortisol } \\
\text { Prednisolone }\end{array}$ & $\begin{array}{l}\text { Cortisone } \\
\text { Prednisone }\end{array}$ & 11-keto & $\downarrow$ & $\begin{array}{l}\text { Cortisol } \\
\text { Prednisolone }\end{array}$ & $\begin{array}{l}\text { Cortisone } \\
\text { Prednisone }\end{array}$ \\
\hline $9 \alpha$-fluoro & $\uparrow$ & $\begin{array}{l}\text { Cortisol } \\
\text { Prednisolone }\end{array}$ & $\begin{array}{l}9 \alpha \text {-fluorocortisol } \\
\text { Isoflupredone }\end{array}$ & $\begin{array}{l}9 \alpha \text {-fluoro } \\
6 \alpha \text {-fluoro }\end{array}$ & $\begin{array}{l}\uparrow \\
\uparrow \\
\uparrow\end{array}$ & $\begin{array}{l}\text { Cortisol } \\
\text { Cortisol } \\
\text { Dexamethasone }\end{array}$ & $\begin{array}{l}9 \alpha \text {-fluorocortisol } \\
6 \alpha \text {-fluorocortisol } \\
\text { Flumethasone }\end{array}$ \\
\hline $6 \alpha$-fluoro & $\uparrow$ & $\begin{array}{l}\text { Cortisol } \\
\text { Dexamethasone }\end{array}$ & $\begin{array}{l}6 \alpha \text {-fluorocortisol } \\
\text { Flumethasone }\end{array}$ & $\Delta 1$-dehydro & $(\downarrow)$ & $\begin{array}{l}\text { Cortisol } \\
9 \alpha \text {-fluorocortisol }\end{array}$ & $\begin{array}{l}\text { Prednisolone } \\
\text { Isoflupredone }\end{array}$ \\
\hline$\Delta 1$-dehydro & $\begin{array}{c}\uparrow \\
(\uparrow)\end{array}$ & $\begin{array}{l}\text { Cortisol } \\
9 \alpha \text {-fluorocortisol }\end{array}$ & $\begin{array}{l}\text { Prednisolone } \\
\text { Isoflupredone }\end{array}$ & $\begin{array}{l}6 \alpha \text {-methyl } \\
16 \alpha \text {-methyl }\end{array}$ & $(\uparrow)$ & $\begin{array}{l}\text { Prednisolone } \\
\text { Isoflupredone }\end{array}$ & $\begin{array}{l}6 \alpha \text {-methylprednisolone } \\
\text { Dexamethasone }\end{array}$ \\
\hline $6 \alpha$-methyl & $\uparrow$ & Prednisolone & $6 \alpha$-methylprednisolone & $16 \beta$-methyl & $\downarrow$ & Isoflupredone & Betamethasone \\
\hline $16 \alpha$-methyl & $(\uparrow)$ & $\begin{array}{l}\text { Isoflupredone } \\
\text { Isoflupredone }\end{array}$ & $\begin{array}{l}\text { Dexamethasone } \\
\text { Betamethasone }\end{array}$ & 16-methylene & $\downarrow$ & Prednisolone & $\begin{array}{l}\text { Prednylidene } \\
\text { Deflazacort }\end{array}$ \\
\hline $\begin{array}{l}16 \beta \text {-methyl } \\
16 \text {-methylene }\end{array}$ & $\stackrel{(\uparrow)}{\uparrow}$ & $\begin{array}{l}\text { Isoflupredone } \\
\text { Prednisolone }\end{array}$ & $\begin{array}{l}\text { Betamethasone } \\
\text { Prednylidene }\end{array}$ & $\begin{array}{l}\text { 21-acetyl } \\
\text { 16,17-methyl- } \\
\text { oxazoline }\end{array}$ & $\downarrow$ & $\begin{array}{l}\text { Desacetyldeflazacort } \\
\text { Prednisolone }\end{array}$ & Desacetyldeflazacort \\
\hline $\begin{array}{l}\text { 16-hydroxy } \\
21 \text {-acetyl } \\
\text { 16,17-methyl- } \\
\text { oxazoline }\end{array}$ & $\begin{array}{c}\downarrow \\
\downarrow \\
(\uparrow)\end{array}$ & $\begin{array}{l}\text { Isoflupredone } \\
\text { Desacetyldeflazacort } \\
\text { Prednisolone }\end{array}$ & $\begin{array}{l}\text { Triamcinolone } \\
\text { Deflazacort } \\
\text { Desacetyldeflazacort }\end{array}$ & & & & \\
\hline
\end{tabular}

The GC potency of dexamethasone in vivo is reported to be slightly higher than $(24,35)$ or equal to $(21,23)$ that of betamethasone. We observed a moderately higher transactivation activity of betamethasone compared with dexamethasone. $9 \alpha$-fluorocortisol, $6 \alpha$-methylprednisolone, desacetyldeflazacort and prednisolone all showed similar $\mathrm{EC}_{50}$ values of approximately 2 to $7 \times 10^{-9} \mathrm{M}$ in our GR assay, in an order that corresponds well to their in vivo potencies (4).
The comparison of the in vitro activities of deflazacort and desacetyldeflazacort with their in vivo GC potencies illustrates the activation of the prodrug deflazacort to desacetyldeflazacort in vivo.

Aldosterone, the physiological MC, is often described as possessing no GC activity at all. However, we found GR-mediated transactivation by aldosterone, but at concentrations relative to cortisol that are not even reached in primary hyperaldosteronism $(36,37)$.

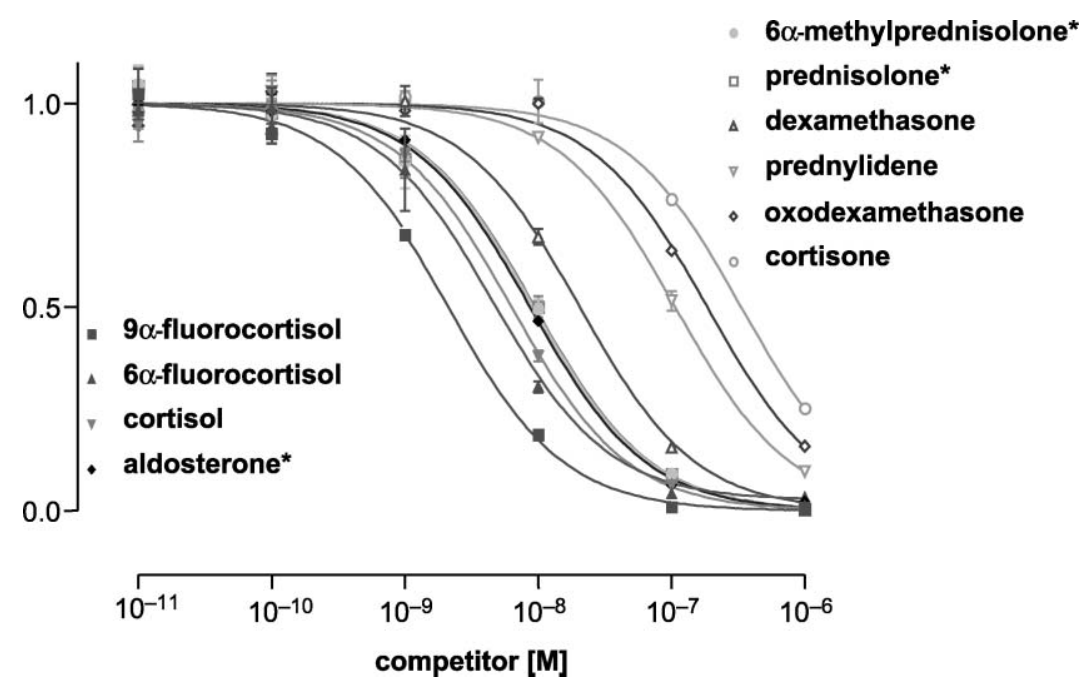

Figure 3 Displacement of $3 \mathrm{H}$-aldosterone from the hMR. Calculated as the ratio of binding in the presence of competitor (B) to maximal binding of $3 \mathrm{H}$-aldosterone $\left(\mathrm{B}_{\max }\right)$ in the absence of competitors. Nonlinear regression curves for one site competition (duplicates). ${ }^{*}$ The curves for aldosterone, $6 \alpha$-methylprednisolone and prednisolone are almost identical. 
The low receptor binding of cortisone and prednisone is well known $(26,35)$. The biological activity of these substances depends on first pass activation by hepatic 11ß-hydroxysteroid-dehydrogenase type 1 (11 $\beta$-HSD1). When cortisone (or prednisone) is injected in an organ without $11 \beta$-HSD1, e.g. intra-articularly, it has no biological activity. This fits well with our results for cortisone and prednisone, which also prove that our assay does not contain relevant amounts of $11 \beta$-HSD1. Progesterone was previously shown to bind to the GR $(26,35)$ but is said to exhibit only slight agonistic activity (38) which was not detected with our assay.

The most noticeable incongruence is the high GC transactivation activity for prednylidene, given an in vivo potency comparable to that of prednisolone. As pharmacokinetics of prednylidene do not explain this discrepancy (39), prednylidene is a good candidate for further pharmacological investigations, e.g. concerning the relation between its transrepression and transactivation activity $(17,40,41)$. The weak transactivation by triamcinolone corresponds to its relatively low receptor affinity (24), but contrasts with its high in vivo potency.

In summary, the influence of a $6 \alpha$ - and $16 \alpha$-methyl substitution, $9 \alpha$-fluorination, 16 $\alpha$-hydroxylation and the $\Delta 1$-dehydro-configuration on transactivation by synthetic GCs via the GR (Table 4) show good correspondence to in vivo data (4). In addition, $6 \alpha$-fluorination, 16-methylene and 16,17-methyloxazoline groups increase GC potency in vitro.

Published comparative data on MC potencies are more scanty. Besides transactivation, MC activity in target tissues depends on prereceptor metabolism by $11 \beta$-hydroxysteroid-dehydrogenase type 2 (11 HSD2), which is co-localized with the MR and inactivates 11-hydroxysteroids to their corresponding 11-oxoderivatives (39). The very poor MR-mediated transactivation (Table 3) of cortisone is a well-known necessity for this gatekeeper effect of the $11 \beta-H S D 2$, which is also true for prednisone.

The $6 \alpha$-methyl group has been reported to diminish MC activity in vivo $(4,23)$. We could not find such an effect in vitro, neither in transactivation (Tables 3 and 4) nor in binding experiments (Fig. 3). Therefore the reduced in vivo MC activity of $6 \alpha-$ methylprednisolone compared with prednisolone may primarily be due to its enhanced GC activity (Tables 2 and 4) resulting in different equivalent dosages $-4 \mathrm{mg}$ of $6 \alpha$-methylprednisolone versus $5 \mathrm{mg}$ of prednisolone - used for pharmacological GC therapy $(4,21,23,25)$.

The prodrug deflazacort exhibits a very low MC activity. At first sight, this seems to support the opinion that deflazacort causes less MC side effects than some of the older steroids. However, as Assandri et al. could show (42), deflazacort is rapidly metabolized to desacetyldeflazacort which does possess some MC activity in our assay.
Complementary to the transactivation assays, binding to the MR was analyzed (see Fig. 3 and Table 5). For most steroids tested, the binding affinity was compatible with the transactivation activity measured (Table 3). One remarkable discrepancy is the MR binding affinity of cortisol being very close to that of aldosterone, while cortisol proved to be the weaker mineralocorticoid in terms of transactivation. Similar binding of aldosterone and cortisol to the hMR, but more potent transactivation via the MR by aldosterone, was described by Rupprecht et al. (38) and Hellal-Lévy et al. (43). The latter group showed that although the affinities for the MR are nearly the same, aldosterone dissociates much slower than cortisol from this receptor, and they assumed different induction of conformation changes of the MR by these ligands. Similarly, almost identical MR binding of aldosterone, $6 \alpha$-methylprednisolone and prednisolone contrasts with our transactivation experiments (Table 3) and in vivo data (4). In general, one can conclude that receptor binding is only a prerequisite of the much more complex process of transactivation, and that a correlation between binding affinities and transactivation properties cannot be assumed a priori for all steroids. A good example for this notion is progesterone (Table 3), which has been shown to possess high affinity to the hMR but causes only minor transactivation at the $\operatorname{MR}(33,38)$ and acts as an antagonist in vivo (44).

The more selective GC transactivation activity of GCs with a $16 \alpha$-methyl or $16 \beta$-methyl group and a $\Delta 1$ dehydro-configuration results from a significantly decreased activity via the MR and an enhanced activity via the GR (Table 4 ). The $\Delta 1$-dehydro-configuration in prednisolone both decreases MC transactivation and increases oxidation by $11 \beta$-HSD2 (39). Fluorination leads to enhanced transactivation (Tables 3 and 4) and attenuated oxidation by $11 \beta-H S D 2$ (39). Therefore, the reduced MC activity in vivo of prednisolone compared with cortisol and the increased activity of fluorinated steroids is probably due both to pharmacokinetic (prereceptor metabolism) and pharmacodynamic (MC transactivation) reasons.

Table 5 Displacement of $3 \mathrm{H}$-aldosterone from human mineralocorticoid receptor (hMR) (see Fig. 3). Given are the concentrations $\mathrm{IC}_{50}$ of the competitors that displace $50 \%$ of $3 \mathrm{H}$-aldosterone.

\begin{tabular}{lc}
\hline Steroid & IC $_{50}[\mathbf{M}]$ \\
\hline $9 \alpha$-fluorocortisol & $2.12 \times 10^{-9}$ \\
$6 \alpha$-fluorocortisol & $4.60 \times 10^{-9}$ \\
Cortisol & $6.34 \times 10^{-9}$ \\
Aldosterone & $8.48 \times 10^{-9}$ \\
$6 \alpha$-methylprednisolone & $9.22 \times 10^{-9}$ \\
Prednisolone & $9.48 \times 10^{-9}$ \\
Dexamethasone & $2.06 \times 10^{-8}$ \\
Prednylidene & $1.07 \times 10^{-7}$ \\
Oxodexamethasone & $1.86 \times 10^{-7}$ \\
Cortisone & $3.35 \times 10^{-7}$ \\
\hline
\end{tabular}




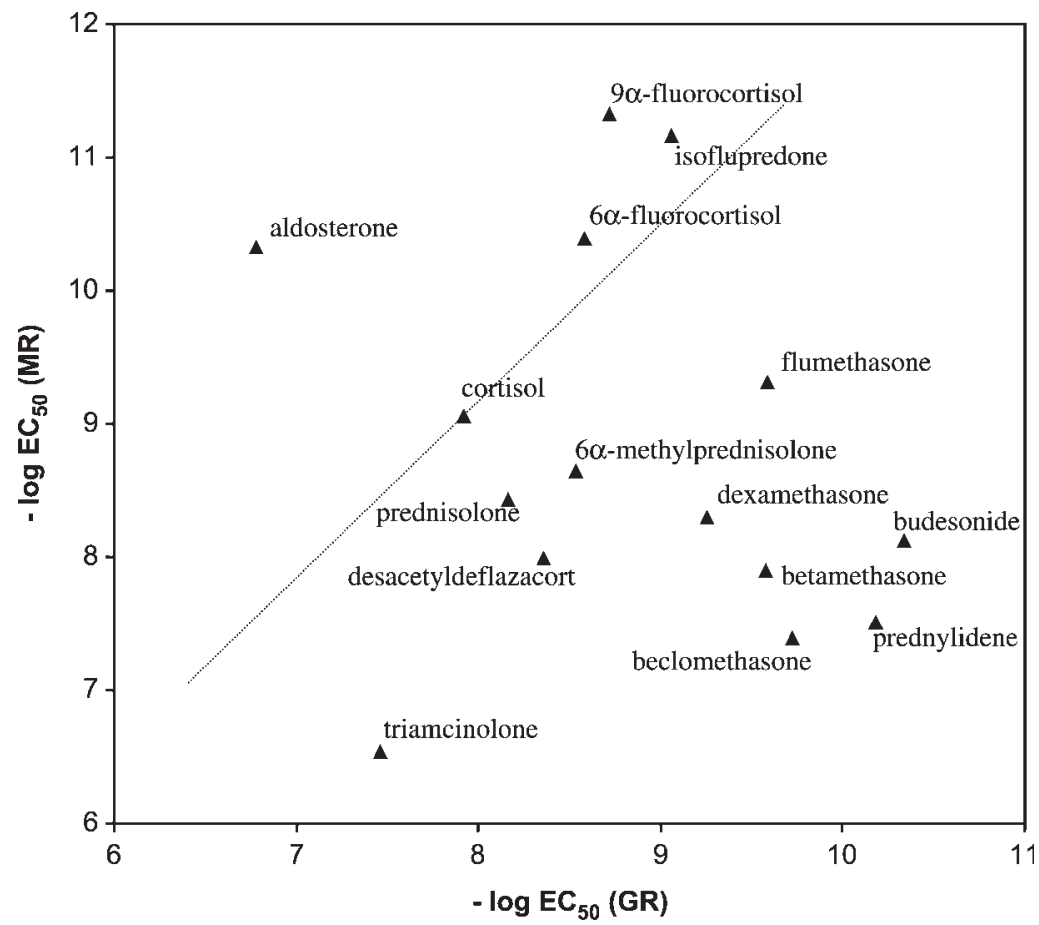

Figure 4 Selectivity of tested steroids. The GC potency increases from left to right and the MC potency increases from bottom to top. The diagonal line seperates typical gluco- from mineralo-corticoids. Selectivity increases with the perpendicular distance from that line: to the bottom right for glucocorticoids, to the top left for mineralocorticoids.

Because some catalytic activity of $11 \beta$-HSD2 has been demonstrated in CV-1 cells (45), an effect of this enzyme in our transactivation assay leading to a shift of $\mathrm{EC}_{50}$ values in either direction cannot be ruled out completely. This may contribute to the weaker effect of cortisol relative to aldosterone in the MR transactivation assay. However, because the $11 \beta-H S D 2$ activity in the CV-1 cells affects the ligand concentration regardless of a transfection with vectors for GR or MR, the ratio of GC to MC potency in our assay is less sensitive to prereceptor metabolism. Therefore this ratio may be a useful parameter for receptor-mediated selectivity. This is illustrated in Fig. 4: highly selective GCs will be found in the lower right quadrant, highly selective MCs in the upper left quadrant. According to the $\mathrm{EC}_{50}$ ratio, the most selective glucocorticoids are prednylidene, budesonide, beclomethasone and betamethasone. The most selective mineralocorticoid is the natural hormone, aldosterone.

It is important to keep in mind that the luciferase assay is an in vitro system which differs from in vivo conditions in many aspects, e.g. altered prereceptor regulation by steroid metabolizing enzymes such as $11 \beta$-HSDs $(39,46-48)$, lacking integration of the reporter gene into chromatine (11) and different concentrations of heat shock proteins, GR (49) and other transcription factors $(8-10,14)$. An important influence of the cell type used in the transactivation assay has been shown (50). Nongenomic effects postulated both for cortisol and aldosterone (19, 51) are neither taken into account. Moreover, transrepression of genes $(1,17,40)$ could not be evaluated by our approach. Therefore, additional testing with transrepression assays is required to detect possible dissociative glucocorticoid effects.

In spite of all constraints, the in vitro assay employed represents a suitable system to compare the specificity of natural and synthetic steroidal homones with regard to the human glucocorticoid and mineralocorticoid receptors. Comparing the influence of further functional groups on transactivation via the hGR and the hMR will help to understand the structure $(52,53)$ and functionality of the substrate binding sites in these receptors.

\section{Acknowledgements}

This work was supported by a grant of the Deutsche Forschungsgemeinschaft (DI 741/1-3). We thank Prof. R Evans, Prof. M Rafestin-Oblin and Dr B Gellersen for their generous gifts of the plasmids, and Dr D Seidelmann (Schering AG) for methodological advice. Furthermore, we would like to thank $\mathrm{P}$ Exner, U Gruber and Dr B Meyer for general support, technical assistance and help with the preparation of the manuscript. 


\section{References}

1 Adcock IM. Glucocorticoid-regulated transcription factors. Pulmonary Pharmacology \& Therapeutics 200114 211-219.

2 Podolsky DK. Inflammatory bowel disease. New England Journal of Medicine 2002347 417-429.

3 Neeck G. Fifty years of experience with cortisone therapy in the study and treatment of rheumatoid arthritis. Annals of the New York Academy of Sciences 2002966 28-38.

4 Fried J \& Borman A. Synthetic derivates of cortical hormones. Vitamins and Hormones $195816303-374$.

5 Arriza JL, Weinberger C, Cerelli G, Glaser TM, Handelin BL, Housman DE et al. Cloning of human mineralocorticoid receptor complementary DNA: structural and functional kinship with the glucocorticoid receptor. Science $1987237268-275$.

6 Evans RM. The steroid and thyroid hormone receptor superfamily. Science $1988 \mathbf{2 4 0} 889-895$.

7 Ribeiro RC, Kushner PJ \& Baxter JD. The nuclear hormone receptor gene superfamily. Annual Review of Medicine $1995 \mathbf{4 6}$ $443-453$.

8 Pratt WB \& Toft DO. Steroid receptor interactions with heat shock protein and immunophilin chaperones. Endocrine Reviews 1997 18 306-360.

9 DeFranco DB. Role of molecular chaperones in subnuclear trafficking of glucocorticoid receptors. Kidney International $2000 \mathbf{5 7}$ $1241-1249$

10 Hellal-Lévy C, Fagart J, Souque A \& Rafestin-Oblin ME. Mechanistic aspects of mineralocorticoid receptor activation. Kidney International $2000 \mathbf{5 7} 1250-1255$.

11 Htun H, Barsony J, Renyi I, Gould DL \& Hager GL. Visualization of glucocorticoid receptor translocation and intranuclear organization in living cells with a green fluorescent protein chimera. PNAS 199693 4845-4850.

12 Fejes-Toth G, Pearce D \& Naray-Fejes-Toth A. Subcellular localization of mineralocorticoid receptors in living cells: effects of receptor agonists and antagonists. PNAS 199895 2973-2978.

13 Liu W, Wang J, Sauter NK \& Pearce D. Steroid receptor heterodimerization demonstrated in vitro and in vivo. PNAS 199592 $12480-12484$

14 Glass CK. Differential recognition of target genes by nuclear receptor monomers, dimers, and heterodimers. Endocrine Reviews 1994 15 391-407.

15 Malkoski SP, Handanos CM \& Dorin RI. Localization of a negative glucocorticoid response element of the human corticotropin releasing hormone gene. Molecular and Cellular Endocrinology $1997127189-199$

16 Reichardt HM, Tuckermann JP, Göttlicher M, Vujic M, Weih F, Angel P et al. Repression of inflammatory responses in the absence of DNA binding by the glucocorticoid receptor. EMBO Journal $2001207168-7173$.

17 Adcock IM \& Caramori G. Cross-talk between pro-inflammatory transcription factors and glucocorticoids. Immunology and Cell Biology 200179 376-384.

18 Schmidt BM, Gerdes D, Feuring M, Falkenstein E, Christ M \& Wehling M. Rapid, nongenomic steroid actions: a new age? Frontiers in Neuroendocrinology 200021 57-94.

19 Losel RM, Feuring M, Falkenstein E \& Wehling M. Nongenomic effects of aldosterone: cellular aspects and clinical implications. Steroids $200267493-498$.

20 Köppel H, Christ M, Yard BA, Bar PC, Van Der Woude FJ \& Wehling M. Nongenomic effects of aldosterone on human renal cells. Journal of Clinical Endocrinology and Metabolism $2003 \mathbf{8 8}$ $1297-1302$.

21 Schimmer BP \& Parker KL. Adrenocorticotropic Hormone; Adrenocortical Steroids and Their Synthetic Analogs; Inhibitors of the Synthesis and Actions of Adrenocortical Hormones. In Goodman and Gilman's The Pharmacological Basis of Therapeutics, 10th ed., pp 1649-1678. Eds JG Hardman, LE Limbird \& A Goodman \& Gilman. New York: McGraw-Hill, 2001.
22 Baxter JD \& Rousseau GG. Glucocorticoid Hormone Action. Berlin: Springer Verlag, 1979.

23 Forth W, Henschler D, Rummel W \& Starke K. Therapie mit Glucocorticoiden. In Allgemeine und Spezielle Pharmakologie, 7th ed., pp 622-624. Spektrum Akademischer Verlag, 1996.

24 Rohdewald P. Rehder S \& Würthwein G. Rezeptoraffinität Synthetischer Glukokortikoide. In Therapie mit Glukokortikoiden, pp 39-50. Ed. HM Schulte. Stuttgart, New York: Schattauer Verlag, 1993.

25 Kaiser H \& Kley HK. Cortisontherapie: Corticoide in Klinik und Praxis. Verlag: Georg Thieme, 1997.

26 Raynaud JP, Bouton MM, Moguilewsky M, Ojasoo T, Philibert D, Beck G et al. Steroid hormone receptors and pharmacology. Journal of Steroid Biochemistry 198012 143-157.

27 Dahlberg E, Thalen A, Brattsand R, Gustafsson JA, Johansson U, Roempke K et al. Correlation between chemical structure, receptor binding, and biological activity of some novel, highly active, $16 \alpha, 17 \alpha$-acetal-substituted glucocorticoids. Molecular Pharmacology 198425 70-78.

28 Rupprecht R, Arriza JL, Spengler D, Reul JM, Evans RM, Holsboer F et al. Transactivation and synergistic properties of the mineralocorticoid receptor: relationship to the glucocorticoid receptor. Molecular Endorinology 19937 597-603.

29 Giguere V, Hollenberg SM, Rosenfeld MG \& Evans RM. Functional domains of the human glucocorticoid receptor. Cell $1986 \mathbf{4 6}$ 645-652.

30 Chandler VL, Maler BA \& Yamamoto KR. DNA sequences bound specifically by glucocorticoid receptor in vitro render a heterologous promoter hormone response in vivo. Cell $1983 \quad 33$ 489-499.

31 Gellersen B, Kempf R, Telgmann R \& DiMattia GE. Nonpituitary human prolactin gene transcription is independent of Pit-1 and differentially controlled in lymphocytes and in endometrial stroma. Molecular Endorinology 19948 356-373.

32 Lorenz WW, McCann RO, Longiaru M \& Cormier MJ. Isolation and expression of a cDNA encoding Renilla reniformis luciferase. PNAS $1991884438-4442$.

33 Quinkler M, Meyer B, Bumke-Vogt C, Grossmann C, Gruber U, Oelkers W et al. Agonistic and antagonistic properties of progesterone metabolites at the human mineralocorticoid receptor. European Journal of Endocrinology 2002146 789-799.

34 Fagart J, Wurtz JM, Souque A, Hellal-Lévy C, Moras D \& RafestinOblin ME. Antagonism in the human mineralocorticoid receptor. EMBO Journal $1998173317-3325$.

35 Ballard PL, Carter JP, Graham BS \& Baxter JD. A radioreceptor assay for evaluation of the plasma glucocorticoid activity of natural and synthetic steroids in man. Journal of Clinical Endocrinology and Metabolism 197541 290-304.

36 Trenkel S, Seifarth C, Schobel H, Hahn EG \& Hensen J. Ratio of serum aldosterone to plasma renin concentration in essential hypertension and primary aldosteronism. Experimental and Clinical Endocrinology \& Diabetes $200211080-85$.

37 Oelkers W, Diederich S \& Bähr V. Primary hyperaldosteronism without suppressed renin due to secondary hypertensive kidney damage. Journal of Clinical Endocrinology and Metabolism 2000 85 3266-3270.

38 Rupprecht R, Reul JM, van Steensel B, Spengler D, Soder M, Berning B et al. Pharmacological and functional characterization of human mineralocorticoid and glucocorticoid receptor ligands. European Journal of Pharmacology 1993 247 145-154.

39 Diederich S, Eigendorff E, Burkhardt P, Quinkler M, Bumke-Vogt C, Rochel M et al. 11ß-hydroxysteroid dehydrogenase types 1 and 2: an important pharmacokinetic determinant for the activity of synthetic mineralo- and gluco-corticoids. Journal of Clinical Endocrinology and Metabolism 200287 5695-5701.

40 Göttlicher M, Heck S \& Herrlich P. Transcriptional cross-talk, the second mode of steroid hormone receptor action. Journal of Molecular Medicine 199876 480-489. 
41 Belvisi MG, Brown TJ, Wicks S \& Foster ML. New glucocorticosteroids with an improved therapeutic ratio? Pulmonary Pharmacology E Therapeutics $2001 \mathbf{1 4} 221-227$.

42 Assandri A, Buniva G, Martinelli E, Perazzi A \& Zerilli L. Pharmacokinetics and metabolism of deflazacort in the rat, dog, monkey and man. Advances in Experimental Medicine and Biology 1984 $1719-23$.

43 Hellal-Lévy C, Couette B, Fagart J, Souque A, Gomez-Sanchez C \& Rafestin-Oblin ME. Specific hydroxylations determine selective corticosteroid recognition by human glucocorticoid and mineralocorticoid receptors. FEBS Letters $1999 \mathbf{4 6 4}$ 9-13.

44 Quinkler M \& Diederich S. Difference of in vivo and in vitro antimineralocorticoid potency of progesterone. Endocrine Research 200228 465-470.

45 Lombès M, Kenouch S, Souque A, Farman N \& Rafestin-Oblin ME The mineralocorticoid receptor discriminates aldosterone from glucocorticoids independently of the $11 \beta$-hydroxysteroid dehydrogenase. Endocrinology 1994135 834-840.

46 Quinkler M, Oelkers W \& Diederich S. Clinical implications of glucocorticoid metabolism by $11 \beta$-hydroxysteroid dehydrogenases in target tissues. European Journal of Endocrinology 2001 $14487-97$.

47 Diederich S, Hanke B, Burkhardt P, Müller M, Schöneshöfer M, Bähr V et al. Metabolism of synthetic corticosteroids by $11 \beta$ hydroxysteroid dehydrogenases in man. Steroids $1998 \mathbf{6 3}$ $271-277$.

48 Oelkers W, Buchen S, Diederich S, Krain J, Muhme S \& Schöneshöfer M. Impaired renal $11 \beta$-oxidation of $9 \alpha$-fluorocortisol: an explanation for its mineralocorticoid potency. Journal of Clinical Endocrinology and Metabolism 199478 928-932.

49 Szapary D, Xu M \& Simons SS Jr. Induction properties of a transiently transfected glucocorticoid-responsive gene vary with glucocorticoid receptor concentration. Journal of Biological Chemistry $199627130576-30582$.

50 Lim-Tio SS, Keightley MC \& Fuller PJ. Determinants of specificity of transactivation by the mineralocorticoid or glucocorticoid receptor. Endocrinology 1997138 2537-2543.

51 Christ M, Haseroth K, Falkenstein E \& Wehling M. Nongenomic steroid actions: fact or fantasy? Vitamins and Hormones 199957 $325-373$.

52 Bledsoe RK, Montana VG, Stanley TB, Delves CJ, Apolito CJ, McKee DD et al. Crystal structure of the glucocorticoid receptor ligand binding domain reveals a novel mode of receptor dimerization and coactivator recognition. Cell 2002110 93-105.

53 Kauppi B, Jakob C, Farnegardh M, Yang J, Ahola H, Alarcon M et al. The 3D-structures of antagonistic and agonistic forms of the glucocorticoid receptor ligand-binding domain; RU-486 induces a transconformation that leads to active antagonism. Journal of Biological Chemistry $2003 \mathbf{2 7 8} 22748$-22754.

Received 5 January 2004

Accepted 3 March 2004 